\title{
CONCESSÕES E PARCERIAS PÚBLICO-PRIVADAS NO DESENVOLVIMENTO URBANO ${ }^{1}$
}

Jean Marlo Pepino de Paula²

\section{INTRODUÇÃO}

Esta nota de pesquisa apresenta reflexôes iniciais no contexto da formulação da Política Nacional de Desenvolvimento Urbano (PNDU). O Ipea firmou um acordo de cooperação com a Secretaria Nacional de Desenvolvimento Regional e Urbano (SDRU), do Ministério do Desenvolvimento Regional (MDR), para subsidiar a elaboração do respectivo plano. O desenvolvimento urbano está sendo enfrentado pelo governo federal com um duplo enfoque da construção social e interfaces com sua dimensão operacional, explorando uma noção ativa, para a qual convergem reflexôes e agendas diversas, que variam nos contextos socioespaciais e temporais.

Esses termos indicam a multiplicidade de aspectos e escalas que caracterizam a organicidade do desenvolvimento urbano e exacerbam a interdependência entre serviços variados, cada vez mais dissociados do poder público. Nesse contexto, a PNDU se apresenta como um instrumento do tipo guarda-chuva, elaborado para promover a harmonia entre disciplinas e entes da Federação e estimular habilidades e o aprimoramento contínuo, circunscrevendo as competências da Uniáo a serem operacionalizadas para tanto.

Apesar dessa diversidade, as discussóes iniciais entre o Ipea e a SDRU/MDR apontaram para quatro dimensóes do desenvolvimento urbano a partir de iniciativas internacionais como os Objetivos do Desenvolvimento Sustentável (ODS) e a Nova Agenda Urbana (NAU).

- Dimensão social: atinente à inclusão, segurança, resiliência e sustentabilidade.

- Dimensão econômica: referente aos padróes de produção e consumo.

- Dimensão ambiental: envolve os desafios climáticos.

- Dimensão político-institucional: trata do relacionamento com a sociedade e da organização e gestão de recursos e iniciativas.

Ainda que o desenvolvimento urbano seja tratado por meio de dimensôes relevantes, a interdependência entre elas é inevitável. Um exemplo disso é a atuação institucional para promover uma conscientizaçáo social sobre o ciclo de vida de produtos, padróes de consumo

1. DOI: http://dx.doi.org/10.38116/brua24art20

2. Técnico de planejamento e pesquisa na Diretoria de Estudos e Políticas Regionais, Urbanas e Ambientais (Dirur) do Ipea. 
e seus impactos ambientais, econômicos e sociais, valendo-se do sucesso dessas dimensôes para retroalimentar sua legitimidade e utilidade.

Essas causalidades e o fluxo de benefícios ainda são pouco discutidos no país e possuem elevado teor teórico e subjetivo, carecendo de evidências consistentes para qualificar os processos decisórios e legitimar políticas públicas. São lacunas como a baixa expressividade dos impactos promovidos pela melhoria da mobilidade ou do saneamento na saúde e na educaçáo, ou ainda a crescente dependência de iniciativas como essas de fontes ininterruptas de energia e comunicação. A fragilidade, a inexistência ou a abstração dessa visão orgânica resulta em políticas isoladas e míopes em sistemas sobrecarregados, os quais se esforçam para sobreviver à custa de fontes de recursos imediatos, aplicados de forma indiscriminada.

Em muitos casos, o vulto e a complexidade das intervençôes são incompatíveis com as capacidades locais disponíveis. Exigem conhecimentos e habilidades específicas e temporárias que podem ser complementadas por uma rede de parcerias com universidades, municípios limítrofes, esferas administrativas e empresas privadas. Essas redes são fortalecidas por normativas e arcabouços legais comuns em busca de um ambiente seguro, bem como compartilham conhecimento, habilidades e tecnologias.

Ocorre, em relação a seus insumos, da mesma forma - eles são frequentemente indisponíveis ou insuficientes. Assim, em meio ao esforço para lidar com a diversidade que envolve o desenvolvimento urbano, o financiamento tem se mostrado uma restrição comum a todas as iniciativas, independentemente da relevância da disciplina. Por isso, modelos de negócios estão sendo estruturados para complementar requisitos, alinhar objetivos e atrair parceiros por meio do compartilhamento de responsabilidades e da entrega de benefícios mútuos.

\section{SURGIMENTO E APLICAÇÃO DAS PARCERIAS NAS POLÍTICAS PÚBLICAS}

Almeida ${ }^{3}$ relata que o termo parceria público-privada (PPP) foi cunhado no final da década de 1960 para tratar da ausência dessas colaboraçôes nas organizaçóes multilaterais, limitando-se a poucas interaçóes entre doadores e governos nacionais. Para o autor, após a crise econômica internacional na década de 1970, organismos financeiros internacionais avançaram com a proposta, supervalorizando o mercado e perspectivas empresariais, ao mesmo tempo que desqualificavam o papel do Estado e a natureza pública de alguns bens. Dessa maneira, as urgentes reformas subsequentes naturalmente militariam pela redução e incompetência do Estado e pela promoção de capacidades adicionais conjuntas por meio de parcerias empresariais e da sociedade civil, encorajando tanto o apoio técnico como o financeiro.

Para Almeida, ${ }^{4}$ o termo PPP é utilizado pela literatura de modo amplo e dissensual em um plano no qual surgem questionamentos sobre a natureza dos atores, o objeto das parcerias e a alocação de atribuiçóes. Segundo o autor, a restrição das parcerias a atores privados lucrativos não é clara nem justificada, motivo pelo qual deve incluir organizaçôes sem fins lucrativos. A decisão em resolver "problemas coletivos" não necessariamente se refere à provisão de bens públicos, enquanto a desejada partilha de atribuiçóes é questionável, uma

3. Almeida, C. Parcerias público-privadas (PPP) no setor saúde: processos globais e dinâmicas nacionais. Cadernos de Saúde Pública, v. 33, p. e00197316, 2017.

4. Almeida, C. Parcerias público-privadas (PPP) no setor saúde: processos globais e dinâmicas nacionais. Cadernos de Saúde Pública, v. 33, p. e00197316, 2017. 
vez que são definidas unilateralmente e são impositivas - restando ao contratante aceitar ou não tais atribuiçôes.

Firmino ${ }^{5}$ também registra que as PPPs assumem diversos significados e práticas em meio a uma forte expansão no cenário internacional. Entre eles, a autora destaca seu longo prazo de duração, um modelo alternativo de governança e uma nova linguagem para dissimular as intençôes de privatização. A estudiosa propôe uma caracterização mais ampla das PPPs: delimitação compulsória de responsabilidades, riscos e benefícios; custo de transaçáo marcado por incertezas e especificidades; e potencial desequilíbrio de benefícios causado pela assimetria de informaçóes, inibido por processos de contratação e dispositivos contratuais, como a distribuição de riscos e a remuneração por desempenho.

A alocação de atribuiçôes reforça papéis e consequentes capacidades de contratados e contratantes, refletindo o termo parceria como uma associação que visa à troca mútua de benefícios, uma "via de duas mãos". Depende da adequada sinergia entre dois ou mais interessados, sendo esperado que a respectiva legislação estabeleça atribuiçôes para cada envolvido de forma a mitigar e melhor distribuir riscos por meio de uma composição adequada de competências e responsabilidades. Assim, diante de um cenário favorável ao avanço das PPPs, vislumbra-se que o setor público avance para uma perspectiva mais estratégica, tratando-as de forma mais ampla, reconhecendo peculiaridades e fomentando um ambiente positivo à sua proliferação e sustentabilidade.

Para tanto, no que se refere aos subsídios às PPPs na PNDU, propôe-se uma caracterização das empresas licitantes e contratadas, dos entes públicos e do desenvolvimento do conhecimento pelas universidades nacionais. Pretende-se, além de estimular uma perspectiva mais orgânica com informaçóes sobre os setores públicos, privados e a academia, desenhar o citado ambiente positivo por meio de mapas de rede, avançando em direção a um esforço para qualificar os processos decisórios com impactos mais complexos e abstratos.

5. Firmino, S. I. Fatores críticos de sucesso das parcerias público-privadas: aspectos político-institucionais. Estudo de caso das rodovias em Portugal. Revista de Administração Pública, v. 52, n. 6, p. 1270-1281, 2018. 
